\title{
Exploring Africa's Economic Recovery
}

\author{
Pádraig Carmody* \\ Department of Geography, Trinity College Dublin
}

\section{Abstract}

For much of the last 30 years, Africa has commonly been considered the world's greatest developmental failure - plagued by economic decline, corruption, AIDS, environmental degradation and conflict. While the overgeneralised nature of this 'Afro-pessisimist' discourse was problematic, the extent of economic decline of much of the continent cannot be denied. However, more recently, the number of conflicts on the continent has declined, rates of economic growth have dramatically improved and poverty may be reducing for the first time in decades. This article investigates the depth, structure and significance of Africa's current economic recovery. While recent academic work has been paid much attention to the rising role of Chinese trade and investment in the continent, it argues that this is only one among other significant trends explaining the current conjuncture. While investigating the environmental and economic impacts of recent Chinese trade and investment, the article seeks explores whether or not the re-alignment of differently scaled social processes opens up the possibility of a poverty-reducing 'developmental regime' for the continent.

\section{Introduction: From 'Lost Continent' to Revival? The Redevelopment of Capitalism in Africa}

In recent decades, development geographers and political economists have been concerned with the nature, construction and impacts of globalisation in Africa South of the Sahara. In particular, they have explored the ways in which people and places have experienced 'adverse differential incorporation' into the global economy (Bush 2007). However, increasing interconnectedness between places (globalisation) is a contradictory process, generating inclusion and exclusion simultaneously, rather than being a fixed-end state. Thus, it also presents opportunities for African economies, such as better global market access (Stiglitz 2005).

In the wake of the debt crisis of the 1970s, and consequent austerity programmes sponsored by the World Bank and International Monetary Fund (IMF), the 1980s and 1990s were the 'lost decades' for development in much of Africa. Much of the continent appeared to be becoming part of the 'Fourth World' - unworthy even of exploitation by global capital (Castells 1998). Poverty increased and the economic base of the continent declined 
- with small (in terms of population), though significant exceptions such as Botswana and Mauritius. For example, gross domestic product (GDP) per capita for sub-Saharan Africa (SSA), excluding the 'economic giants' of South Africa and Nigeria, fell 2.1\% in 1980, and 2.3\% in 1990 (World Bank 2006a). In part, this was to do with price reductions for primary commodities - Africa's main exports.

According to the United Nations Conference on Trade and Development (cited in Bond 2005), if the terms of trade (prices for imports versus exports) had stayed the same for Africa from 1980 to 2000, the continent would have had twice the share of global trade that it did, and average incomes would have been $50 \%$ higher. In some cases, economic decline was associated with outbreaks of political instability and civil war, as in a context of acute poverty the opportunity cost of involvement in rebellions is near zero (Soludo and Ogbu 2004). In ethnically divided societies with contracting economies competition over resource rents may be particularly acute.

The 2000s have been different, however, given the cyclical nature and evolving spatio-temporality of globalisation. The technologically and institutionally dynamic nature of globalised capitalism creates new alignments between differently scaled social processes, changing the nature of incorporation and opening up and closing down development possibilities for particular places. The geographical boundaries and social nature of inclusion and exclusion are not only constantly reproduced, but also dynamic.

The number of civil wars on the continent has declined since 2002 (Human Security Centre 2005), with seemingly intractable conflicts ending, or at least being substantially brought under control, in Sierra Leone, Liberia, and the Democratic Republic of Congo (Frazer 2006); a new and genocidal one in Darfur, Sudan, notwithstanding. In addition, economic growth has dramatically revived on the continent. Africa now hosts seven of the world's top 20 fastest growing economies (African Business 2007). For example, based on increased oil prices and production, Equatorial Guinea's economy grew at over 20\% p.a. from 1996 to 2005 (Broadman 2007a) and there are now 13 middle-income countries in SSA (Ndulu et al. 2007).

Overall, growth is projected to be $6.1 \%$ for SSA in 2007 by the IMF (2007), just shy of the $7 \%$ that some international plans argue is necessary for sustainable poverty reduction (New Partnership for Africa Develoment [NEPAD] 2001). ${ }^{1}$ Indeed, the World Bank (2006a, 2) claims 'the region's higher economic performance is not transitory but is rather a structural break from the past.' Furthermore, the latest United Nations (2007) Millennium Development Goals Report 2007 statistics show that for the first time in decades poverty in SSA declined from $45.9 \%$ in 1999 to $41.1 \%$ in 2007, although the calculation and meaning of these statistics is open to interpretation and dispute (Kaplinksy 2005; Kiely 2007; Pogge 2002).

Much recent economic growth in Africa has been driven by the impacts of Asian, particularly Chinese and Indian, trade and investment, 


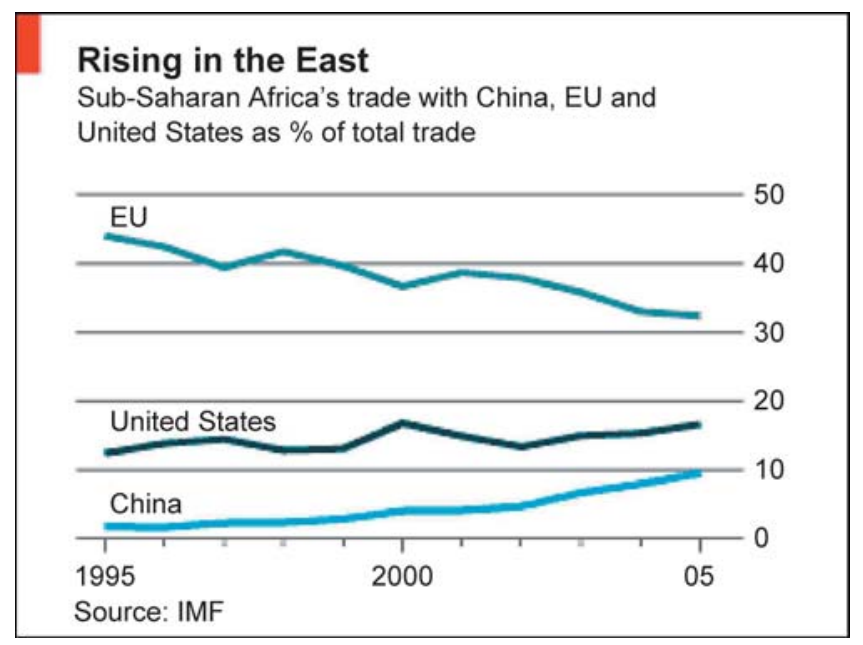

Fig. 1. Reproduced by permission of The Economist.

and US demand for oil (Figure 1), with China taking roughly five times more African exports than India (Broadman 2007b). However, there are questions around whether the extant and emerging economic 'superpowers' increased involvement on the continent will merely re-invigorate and re-inscribe the colonial mineral and cash crop export economy, or whether they might build transformative development partnerships with the continent (Alden 2007). In other words, does their increasing engagement portend an 'African Renaissance', or is it consonant with previous rounds of economic restructuring that will ultimately exacerbate environmental degradation and deepen impoverishment?

One of the problems of capitalist development in Africa has been the long-lived exploitative links or 'intransitive articulation' between it and other peasant modes of production on the continent (Lonsdale 1981). In the 1980s, such was the extent of economic decline that many peasant farmers sought to delink themselves from capitalist trade relations and the exploitations of the state, engaging in a 'silent revolution' by concentrating on subsistence farming (Cheru 1989). However, the recent revival of economic growth and rising commodity prices suggests a deepening of commodity relations on the continent and when combined with large-scale Chinese infrastructural investment this constitutes a round of restructuring (Lovering 1989) that will redevelop capitalism on the continent, although the outcome of this process is, as yet, indeterminate.

This review article seeks to interrogate the drivers, dimensions and durability of Africa's economic recovery. In particular, it seeks to examine whether or not the new scalar alignment constitutes or enables the creation of a poverty reducing 'developmental regime' for the continent (Pempel 
1999). For sustainable development to take place constraints at different scales must be unlocked. ${ }^{2}$ In particular, it examines the impacts of Chinese involvement, as the country with the most rapidly growing presence on the continent.

The article begins by discussing the impacts of recent Asian trade and investment on the continent, noting the complimentary nature of the two regional economies. The next section discusses other global factors in Africa's current economic recovery, particularly higher global economic growth, and the associated and ongoing technological revolution, and the impacts of multilateral debt relief. The subsequent sections discuss the impacts of South Africa's re-integration into the continental economy and changes in national governance. The current growth recovery is heavily resource-driven and the next section discusses the environmental and economic impacts of the commodity boom, followed by a discussion of the impacts on manufacturing. The article concludes with a discussion of future prospects for structural transformation. It argues that while African economies are becoming more resource-based, there is also potential for economic diversification and sustainable poverty reduction if resource rents are captured and 'sown' effectively. Higher prices for exports, cheaper imports, new infrastructural investments, the use of new technologies and debt relief have opened a window of opportunity for the continent. National and regional social struggles for more accountable states and greater autonomy in policymaking will be key to taking advantage of this potentiality.

\section{The New Inter-regionalism: The Asian Connection}

During the 1990s and 2000s, much was written about the need for deeper regional integration in order to renegotiate Africa's engagement with the global economy (e.g. Mittelman 2000). However, Africa's growth dynamic is increasingly driven by Asia: the most dynamic pole of the world economy, as African and Asian growth rates have converged (Ndulu et al. 2007). Many Asian economies have industrialised and have transitioned from colonial-style exporters of raw materials to resource importers. China is now the world's largest consumer of oil and copper (Lemos and Ribeiro 2007).

The explosive growth of the Chinese economy, at $10 \%$ a year for the last 30 years, has sent reverberations around the world. At this growth rate, an economy doubles in size in just over 7 years, and with a population of 1.3 billion people this creates massive demand for resources. Some local examples of how China's demand for resources have been felt worldwide include the theft of 'man-hole' covers from streets around the world during 2004; 24,000 of them in Beijing itself, as the price of steel more than doubled during that year (Muir 2004; Shinan 2005), and the fact that slag heaps outside mines in South Africa are now themselves being mined, as mineral prices have risen (Mining Review 2004). 
There have been dramatic increases in foreign direct investment (FDI) and trade between China and Africa. Asia now takes $27 \%$ of African exports, compared to $14 \%$ in 2000 , whereas the European Union share of African exports halved from 2000 to 2005 (Broadman 2007a). Africa and China are also increasingly linked through networks of hundreds of thousands of African traders living in China and vice versa (Alden 2007). Given the scale of its impact, China's role in Africa is now the primary issue of concern in Africa's international relations (Taylor 2006; see also Mawdsley 2007).

There are over 800 state-owned Chinese companies invested in Africa, and China is intent on creating a paradigm of globalisation favourable to it that merges state and market mechanisms (Alden 2007; Ramo 2004). As many Chinese oil companies, for example, are state-owned and subsidised they can take a long-term strategic approach to business planning, rather than being subject to the imperative and disciplinary effect of quarterly stock market returns. Consequently, the Chinese model of globalisation is in contradistinction to the 'Anglo-American' approach of minimal state involvement in the economy, although Western companies often receive implicit subsidies from their governments via export credit guarantees and tied aid, which contribute substantially to indebtedness in Africa (Hertz 2004).

Chinese interest in Africa has been heavily concentrated in the oil sector, with Nigeria, Angola and Sudan as major exporters. Chinese imports of African oil and gas grew over 50\% per annum from 1994 to 2003 (Rocha 2007). Indeed, oil investment now represents over $50 \%$ of FDI into the continent, mostly into Nigeria and Sudan (Watts 2006; World Bank 2006a). Over $40 \%$ of Sudan's exports now go to China; almost all of it oil. However, perhaps the most important effects of China's growth have been indirect (Broadman 2007a), by driving up commodity prices, Africa's main exports, globally (Figure 2). Asia is acting as the 'locomotive' for the global economy as it imports more from the developed economies, which then grow and import more from Africa (Jenkins and Edwards 2006).

Oil prices have also been affected by supply constrictions resulting from the war in Iraq, the country with the world's second largest reserves of oil (Klare 2005). Also, as 'peak oil' approaches, when more than half of the world's reserves are exhausted, but the global economy continues to expand, prices will inevitably continue to rise. China by itself accounts for $40 \%$ of total global growth in oil demand (US Energy Information Administration cited in Pan 2006). Some refer to the growth dynamic of global capitalism in the context of finite natural resources as generating an 'ecological contradiction' (O'Connor 1994). This contradiction finds geographical expression in the plundering ${ }^{3}$ of African resources and environments to fuel economic growth elsewhere. This is facilitated, for example, by planes taking food from Africa to feed Europe bringing arms in exchange (Sauper 2006).

Primary commodities represent around $80 \%$ of SSA's merchandise or commodity exports (Siddiqi 2007a). Indeed, in 2006, energy and metals accounted for $75 \%$ of Africa's total exports (Siddiqi 2007b). This export 


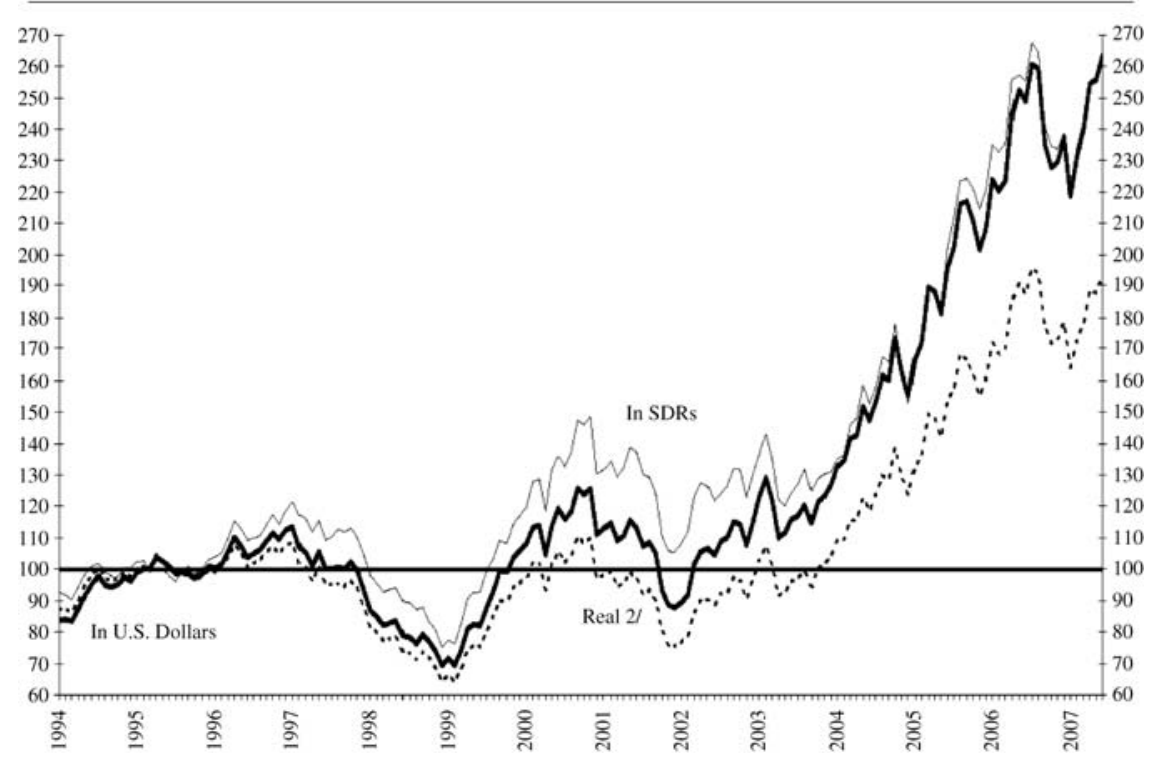

Fig. 2. Primary Commodity Price Index in real (adjusted for inflation) terms, and in U.S. dollars and Special Drawing Rights (SDRs). Reproduced by permission of the International Monetary Fund.

profile is leading to a regionalisation of trade with Asia, with East Africa primarily supplying agricultural goods, Central and Southern Africa supplying minerals and the Sahel and West Africa supplying oil (Figure 3). As prices have risen least for agricultural products, the economy of East Africa grow more slowly. Malawi, which recognises Taipei over Beijing, and whose main export is tobacco, saw its economy grow by just 2.6\% in 2005 (World Bank 2007; Field Notes, Lilongwe, Malawi, March 2007). ${ }^{4}$ East Africa was the only one of five subregions in the subcontinent to record a negative trade balance in 2004, equivalent to $12.3 \%$ of GDP, whereas Central and West Africa recorded trade surpluses of $19.7 \%$ and $12.9 \%$, respectively (Organisation for Economic Cooperation and Development and African Development Bank 2006).

Commodity prices are likely to remain higher for the foreseeable future as China and India continue to grow (Zafar 2007), barring a global economic meltdown or recession, both of which remain possible (Dumas and Chylevam 2006; Wehrfritz 2007). However, there are also other factors that are contributing to Africa's economic growth and recovery.

The Global Context and Africa's Recovery: Growth, Technology and Debt Relief 'Unequal trade' (de Janvry 1981) has long bedevilled African economies as prices for primary commodities have tended to fall and prices for higher 


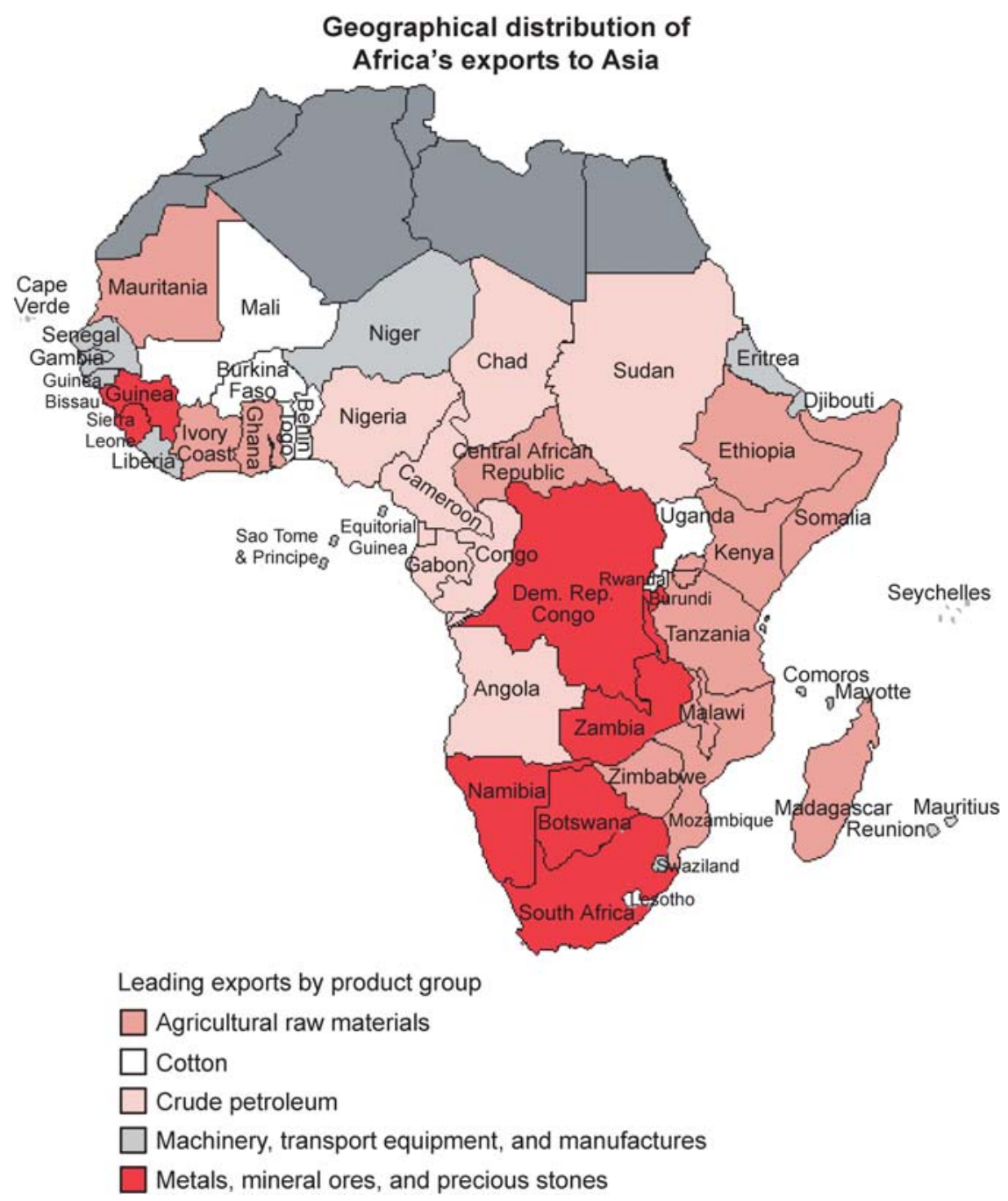

Fig. 3. From Broadman (2007a). Reproduced by permission of the World Bank.

value manufactured products have tended to rise, leading to both trade and debt traps. However, currently, 'there is a significant category of manufactures, particularly those in which China participates, in which prices appear to be falling' (Kaplinksy 2006a, 49). Thus, African countries may gain from lower import prices; except oil, for those that import it (Figure 4). Thus, the structure of Asian growth, combined with the power of major global buyers, such as one of the world's largest companies - Wal-Mart - who engage in 'cost-down' and 'cross-cost' $\mathrm{t}^{5}$ sourcing, may be inducing a secular reversal in the terms of trade between primary and secondary products (Kaplinksy 2005, 2006a). 


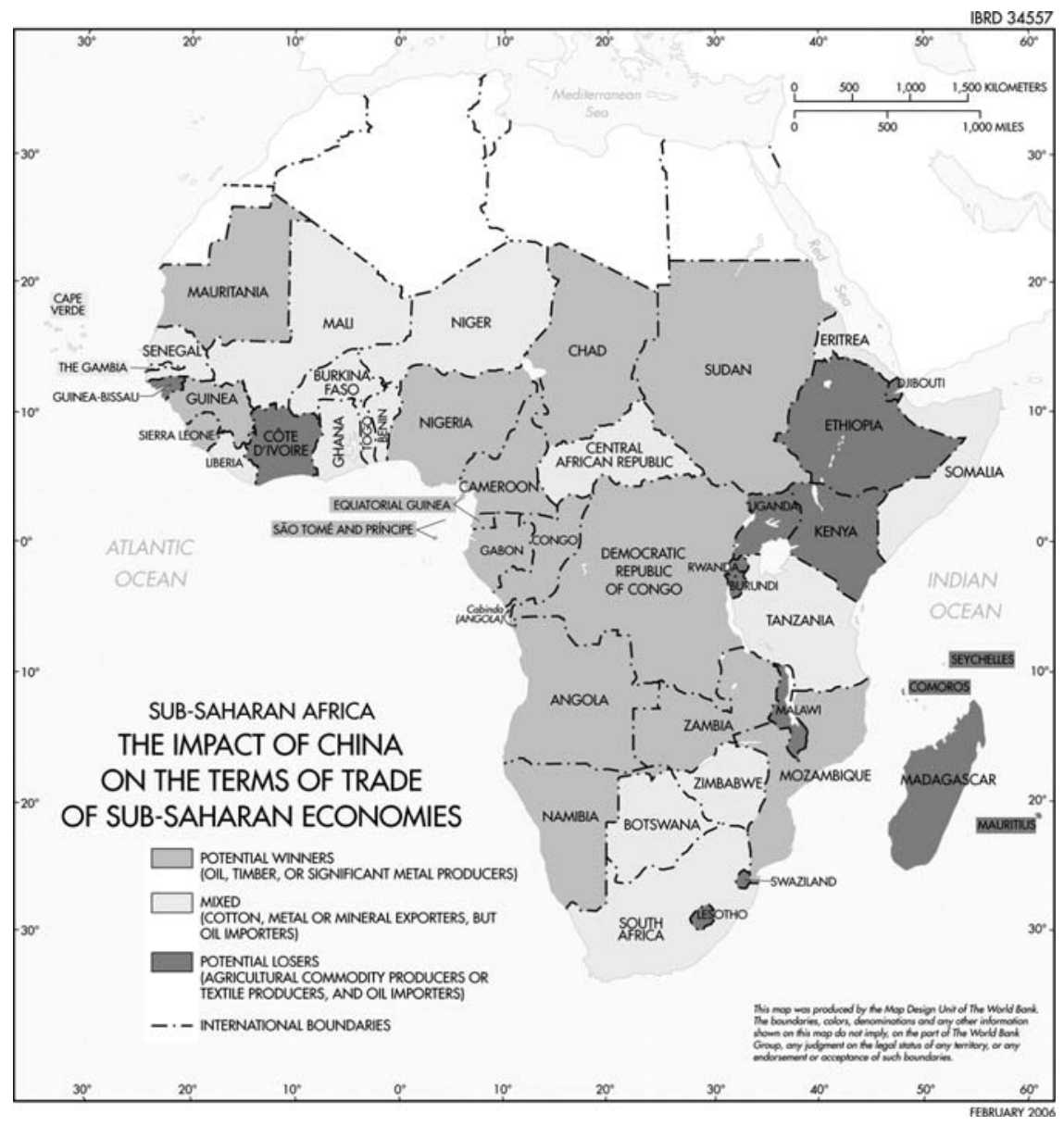

Fig. 4. From Zafar (2007). Reproduced by permission of Oxford University Press.

Arguably, the global economy has entered a new phase, characterised by higher growth, as information and communication technology (ICT) unlocks growth potential across sectors (Perez 2002 cited in Kaplinksy 2005). In the 1990s, Ankie Hoogvelt (1997) characterised the global economic system's geography as one of 'imploding capitalism', as capital flows and trade were largely confined to the rich countries and developing East Asia. However, partly as a result of increased demand for natural resources, the system is now, once again, becoming more geographically extensive.

While still miniscule, in relative terms, Africa's share of global FDI has risen to $1.8 \%$; attracting absolute amounts roughly three times what they were per year in the 1990s (Broadman 2007a; Voltairenet 2007). These developments are related to long cycles of boom and bust in the global economy, based on developments in technology (see Knox and Agnew 
1998), with China now the world's largest exporter of high-tech products (McCormack 2006). However, the diversification of FDI and trade flows is also driven by other economic and political imperatives. For example, larger homes and more sport utility vehicles in America have driven energy consumption higher, as have Internet server farms - each one of which may use the same amount of power as all the homes in a city such as Honolulu (C/NET 2001). Partly as a result, the USA is also eager to diversify oil supplies; away from reliance on the Middle East to Africa and Central Asia (Carmody 2005).

Much of Africa's current growth is driven by oil; by energy usage for consumption in the USA and increased demand from productive uses in China. Ninety-three per cent of SSA exports to the USA, excluding South Africa, were energy products, mostly oil, in 2006 (United States International Trade Commission 2007, quoted by H. Stein, personal communication). While some see the geography of African oil economics as equivalent to a new form of 'triangular trade', similar to slavery, between the USA, Africa and Europe (see Rowell et al. 2005), the 'triangulation effect' on African economies would appear to be more between the USA and China. Indeed, it may be possible to speak of a new 'global growth triangle', with Africa supplying resources, China manufacturing capability and the US consumptive power, partly based on the seigniorage afforded by the dollar still being the primary global reserve currency. For example, Angola is now China's largest supplier of oil (Alden 2007) and the US is China's main export market. These arrangements find institutional expression in the Africa-China-USA trilateral dialogue (Council on Foreign Relations 2007).

The globalised economy is dependent on territorially fixed forms of resource extraction, generating resistance and conflict (Omeje 2005). The extractive social relations and problems that the high-tech oil platforms dotting Africa's coastline bring with them is captured by their local moniker: 'mosquitoes' (Shaxson 2007). However, as Kransberg's first law states: technology is neither good nor bad; it depends on the uses to which it is put: that is, the social relations in which technology is embedded matter.

The ongoing global technological revolution is having other important impacts on Africa. Backwardness can sometimes be advantageous if it creates opportunities for technological 'leapfrogging', as 'late-comer' institutions and capital are not locked into older technologies, enabling quicker uptake and diffusion of new ones (see Okpaku 2006). Mobile phone penetration rates have risen dramatically on the continent, transforming the way in which much business is conducted, through mobile phone banking, for example. The world's largest mobile phone maker, Nokia, sees Asia and Africa as the key growth markets in the next 10 years (Unstrung 2007). In fact, Africa has the fastest growing mobile phone market in the world, growing $66 \%$ in 2005 alone, to now give a total of 250 million subscribers on the continent; up from 10 million in 2000, despite the fact that communication costs are five times higher in relative 
terms than in the developed countries (Africa Monitor 2007; Gillwald 2005; RNCOS 2006).

Peasant farmers may benefit from this technology as they are able to call ahead to find out where to get the best prices for their products (James 2002; Von Braun and Torero 2006), although the poverty reduction potential of ICT usage should not be exaggerated (Duncombe 2006; Muloney 2006). In many countries in Africa, mobile phone companies are among the biggest and largest tax payers (The Economist 2006a). However, one of the largest mobile phone companies on the continent, Celtel, was recently bought by a Kuwaiti company, repeating a historical tendency for successful indigenous businesses to be taken over by foreign capital.

The development of new fibre optic cables linking Africa to other continents has also dramatically reduced the costs of international phone calls and Internet access and opened up new economic activities. Eighty thousand people are now employed in South Africa in call centres (Benner 2006), along with others in Ghana. This will enable many African countries to transcend the colonial legacy where phone calls, even between neighbouring countries, had to be routed through Paris or London, dramatically raising costs.

There is also, however, a menacing underside to this new technology, as control over the precious metal coltan, without which mobile phones and other personal electronic devices would not work, was implicated in the civil and interstate ('cinter-state' or network) war in the Democratic Republic of Congo (DRC) from 1998 to 2003 that killed several million people (Nest 2006). Also the shift to using cassiterite, instead of lead, in electronic circuitry for environmental reasons by the European Union and Japan has also recently been implicated in horrific exploitation and environmental degradation in the DRC (CNN 2006).

If increasing ICT usage may be considered one of the 'positive flows' of globalisation, Africa has experienced many of the 'negative flows', such as debt and resource extraction. However, recently, the global social justice movement has been successful in securing substantial debt relief for heavily indebted African countries. In 1996, SSA's external debt was equivalent to $104 \%$ of GDP, making it the most heavily indebted region of the world in relative terms (Carmody 2001). This had fallen to $51 \%$ by 2004 , and the IMF estimates it will fall to $25 \%$ in 2008 (IMF 2007).

Debt relief is tied to neoliberal free market reforms that have been associated with increased poverty and inequality in the past, and certain types of debt, such as that incurred under export guarantee schemes, is not included in the Multilateral Debt Relief Initiative (Stein 2007). However, those countries that can escape the debt trap, can potentially invest in infrastructure and human capital up-grading, which can contribute to economic growth, as can recently increased (though erratic) aid levels. For example, as 'user fees' for primary school have been abolished in many countries as part of their 'Poverty Reduction Strategy Papers', ${ }^{6}$ enrolment 
rose from 56\% in 1999 to $64 \%$ in 2004 in SSA (Stein 2007). Although higher enrolments resulting from this 'liberalisation of education' have put pressure on educational systems throughout Africa, with quality often suffering as a result. In Malawi, ' $60 \%$ of the public resources at this level are used on children who drop out before finishing primary or on children repeating a year' (World Bank 2004, 7). In addition to these factors operating at a global level, the re-integration of the South African economy into the region has had substantial impacts.

\section{'Bestriding the Continent Like a Colossus', or a Lilliputian?: South Africa's Regional Impact}

Nigeria and South Africa are, by far, the two largest economies in SSA, with the latter more than three times bigger than the former (calculated from World Bank 2006b). The growth and reintegration of South Africa's economy into its subregion and the subcontinent after the fall of apartheid has had important economic impacts. South African companies are the third largest 'foreign' investors in Africa, after France and somewhat surprisingly the Netherlands, although it is the headquarters of companies like Shell Oil (United Nations Conference on Trade and Development 2005 cited in Frynas and Paulo 2007). For example, South African investment, particularly in the multibillion dollar aluminum plant in Mozambique Mozal - is largely responsible for that country having an average 8\% economic growth rate p.a. over the past decade (Kaminski 2007; Lockwood 2005). Although high rates of growth are easier off a low base, GDP per capita is still only US $\$ 320$, and poverty continues to worsen in the north of the country (Hanlon 2004).

The South African government has been active in brokering peace accords, some would argue in part in order to open up commercial opportunities for its companies. Allied to the peace settlement in the DRC, in which South Africa played a leading role, President Mbeki claimed that a US $\$ 10$ billion deal on trade and investment had been done with the government and that US $\$ 4$ billion worth of World Bank tenders had been garnered for South African companies (Bond 2006; Nest 2006).

As the South African economy, which accounts for over a third of SSA's GDP has been growing strongly in recent years, this has also had a regional multiplier (Keet 2006; see Hirsch 2005 for a discussion). For the first time in decades, South Africa created substantial numbers of jobs in the last few years; over half a million, mostly in horticulture (Integrated Regional Information Network 2006). However, much growth has been based on the 'minerals-energy complex' (Fine and Rustomjee 1996). Nonetheless, the fact that there is a growing regional market in Southern Africa, and that many countries in the region have reduced tariffs far below their World Trade Organisation commitments has made it an attractive base of operations for some Asian companies (Cassim and Mayer 1997 cited in Hentz 2005). 
Whereas South African value-added products were for the most part not competitive on world markets in the initial years after apartheid, they had a competitive edge in the region (Söderbaum 2004). South African retailers now dominate Southern Africa and 'supermarketisation' may mean small-scale farmers do not have outlets for their products (see Humphrey 2007 for a discussion). In supermarkets in Zambia, almost all of the processed products are imported from South Africa, and some fresh ones like eggs (Field Notes, Lusaka, Zambia, January 2007).

In manufactures, South African companies are now often being outcompeted by Asian ones in the region. There are also cases where South African companies are being outbid on mineral exploration rights by Chinese companies. Nonetheless, they remain important actors. To some extent, distinctions based on national ownership are becoming moot as Chinese investors are taking out major stakes in 'South African' companies (Southey 2006). However, the South African impact will likely diminish in relative terms compared to China's as its economy is less than a tenth the size and only growing half as fast (calculated from IMF 2007). South African half year exports to China rose 195\% in 2007 (Hazelhurst 2007). Nonetheless, the South African government remains influential and has spearheaded the NEPAD, which seeks to improve governance on the continent in exchange for more favourable international relationships with the developed countries (see Taylor 2005a).

\section{National Factors: 'Good' Governance}

The World Bank (2001, cited in Mkandawire 2005) attributes much of Africa's improved economic performance to better 'governance' or management of public affairs. In 2002, the African Union estimated that the continent lost up to a quarter of its economy to corruption per year; much of this leaking out in illegal capital flight abroad (BBC 2002). An oft-quoted statistic is that 40\% of Africa's private wealth is held overseas (Collier 2007). The international donor community has conveniently emphasised national governance as the principal challenge facing Africa (an internalist explanation for underdevelopment), rather than factors such as unfair trade and agricultural dumping of subsidised products (global governance), in which they are implicated. Consequently, the international donor community has been supportive of NEPAD as a mechanism to improve governance.

Governance is fundamentally about power and how it is exercised. Donor-promoted 'good governance' seeks to normalise and embed the neoliberal accumulation regime on the continent by disciplining the state so that it cannot 'interfere' in the market (Carmody 2007). However, governance can only be good if it is democratic, so there can be no singular definition (Mkandawire 2007). Nonetheless, macro-economic governance has seen some improvement recently, with inflation now averaging only 
$8 \%$ a year on the continent (Voltairenet 2007), making productive investment more attractive there. Zimbabwe is an outlier, with inflation in the thousands of percent. There shoppers race ahead of store clerks changing prices in supermarkets, when there are things to buy.

A recent World Bank (2007) study also found significant reductions in corruption. In part, this has been driven by disaffection among local voters who have voted in 'new' governments, as in Kenya in 2002. Although there are also continuities with the past, as the current President served as a Vice-President under the previous administration from 1978-88 and some supporters from his ethnic group noted that it was now their 'turn to eat' from the state coffers (Wamwere 2003). The President's dubious re-election in 2007 has also generated mass civil unrest. In another mixed example, former Nigerian President Obasanjo, elected in 1999, although previously a military dictator, was instrumental in setting up an Economic and Financial Crimes Commission. A notable and successful banking reform was also undertaken. Although, when the Finance Minister's anticorruption drive threatened to upset the apple cart prior to the 2007 election, she was transferred to the Foreign Ministry and ultimately forced to resign (Oloja et al. 2007). Thus, neopatrimonialism represents a type of social equilibrium (Van de Waal 2001), although currently under challenge.

According to Christopher Clapham (2006 cited in Naidu 2006) one reason why China's current model of engagement 'without political strings attached' in Africa has achieved its objective to date is precisely that it fits with older models of state patrimonialism. However, Copson (2007, 143) notes that China has interests in improving African state efficiency, if not accountability, as 'corrupt regimes and failing states are not going to be able to maintain Chinese-built infrastructure or repay loans.'

\section{New Wine in Old Bottles? Impacts of the Commodity Boom}

There are then a number of factors that are contributing to Africa's current economic growth; however, chief among these is the commodity boom. The World Bank's chief economist, John Page, has noted that one of the features of Africa currently is the great diversity of economic performance across countries. Others refer to a 'two speed Africa' (Goldstein 2006). From the mid-1990s, 16 SSA countries have seen average economic growth over $4.5 \%$, whereas the 13 slowest growing economies have averaged only $1.3 \%$ (World Bank 2006b). Consequently, the standard deviation of average annual growth in SSA doubled from $2 \%$ to $4 \%$ from the 1980 s to the 2000 s. In large measure, this is driven by differing resource endowments (Zafar 2007; Figure 3), with the fastest growing economies in Africa being 'petro-states'.

Copper production in Zambia has more than doubled from 2000, as the price rose almost seven-fold, before falling back more recently (The Economist 2005, 2006b; Siddiqi 2007b). Copper and copper products dominate the country's export basket, as along with the associated mineral 
cobalt, they account for almost $80 \%$ of exports (CSO 2007). Much of the new investment, including a touted copper smelter, is being undertaken by Chinese companies (Mulenga 2006). While the new jobs and economic growth created by the revival of the industry are to be welcomed, there are a number of concerns. The industry is characterised by a harsh labour regime, as in some Chinese-owned mines labourers never get a day off (Dixon 2006). Wages are very low, with workers at the Chambishi mine in Zambia paid US\$45 a month (Sautman and Hairong 2006). Safety standards are also poor, as an explosion that killed dozens of people at one of the mines in 2006 demonstrated. Also, as copper is a non-renewable resource, there are concerns about the sustainability of the industry. Indeed, a recent report for the World Bank (2006c cited in Bond 2006) found that if the costs of depletion were included, Africa is being impoverished by the emphasis on natural resource exports.

The people of Zambia are seeing few benefits from their natural resources. Under the auspices of the World Bank and IMF, in order to attract foreign investors during the privatisation of the copper industry in the late $1990 \mathrm{~s}$ the government's royalty fee was set at $0.6 \%$; meaning the country's resource were essentially being given away for free, just before the commodity price boom began (see Kaunda 2002 for a discussion of the privatisation). The power balance has now shifted somewhat, however, and there is now scope to renegotiate contracts, as Liberian President Ellen Shirlaff Johnson has done for iron ore deposits with the Indian company Mittal (Alden 2007). Many governments remain leery of disturbing 'investor confidence', although concerns over corruption have also led to cancellation of some contracts in the DRC (e.g. The Economist 2007).

Collier (2007) discounts the impacts of the current boom as short-lived and previous 'stop-go' growth dependent on changing conditions in the global economy has not been conducive to poverty reduction (Amoako 2003). A serious economic impact of the current resource boom is that many African economies are experiencing 'Dutch disease'. When export receipts go up, hard currency such as dollars become more plentiful and consequently less of the local currency is required to buy them. The impact of this is to make imports cheaper and exports of manufactures and other price-sensitive goods less competitive, reinforcing dependence on resource exports. During Gabon's oil boom in the 1980s, 96\% of food was imported (Ghazvinian 2007). While two-thirds of Gabon's population live on less than a dollar a day, the capital, Libreville, is more expensive than London or New York, and per head it is the world's leading consumer of champagne (Shaxson 2007).

The recent appreciation of the Zambian currency has put pressure on the horticulture sector that was meant to help diversify the economy (Voltairenet 2007). While horticulture exports continue to grow in some countries, accounting for $65 \%$ of all of Kenya's export to the European Union, this has problems associated with it as it is often undertaken on large estates, exacerbating class inequality. In Kenya, 13 companies account 
for $90 \%$ of the country's fresh vegetable exports (Broadman 2007a), although its development has sometimes been associated with absolute poverty reduction (see English et al. 2006). Nonetheless, horticultural estates may monopolise water supplies, to the detriment of local small-scale farmers (Vidal 2006). ${ }^{7}$ Furthermore, some non-traditional exports are capital rather than labour-intensive in Africa, such as aquaculture that uses automated fish-feeding systems (Mytelka 2003).

Africa's reliance on primacy commodity exports is problematic because of the potential for price instability, lack of linkage effects in local economies, lack of technological dynamism and environmental impacts. Extensive oil and mineral deposits have also often been associated with conflict - the 'resource curse'. Some research suggests that countries rich in resources have a $23 \%$ chance of experiencing conflict in any given 5 -year period, whereas for countries without resources the figure is $0.5 \%$ (Collier and Bannon 2003; see also Billon 2007 for a discussion). In some cases, the 'plunder economy' (Cramer 2006), put in place during slavery and colonialism, is being reinforced.

Environmentally, there are severe impacts of the resource boom. China imports almost half of Gabon's total forest exports; much of it illegally harvested (Toyne et al. 2002 cited in Chan-Fishel 2007). The current deforestation process in Mozambique is referred to as the 'Chinese takeaway' and a Chinese ship is reported to have docked in Mozambique with 4 tons of shark fins, leading to accusations of resource colonialism. In some cases, this risks regional species extinction, with $90 \%$ of Southern Africa's abalone shellfish harvested in the last few years (Alden 2007). There are also major concerns in Mozambique about the proposed Chinese-funded US $\$ 2.3$ billion Mphanda Nkuwa dam, particularly given the country's seismic risk as it recently recorded a 7.5 earthquake on the Richter scale (Lemos and Ribeiro 2007). Consequently, there have been a series of environmental conflicts associated with Chinese investment.

In 2006, the guerrilla group, the Movement for the Emancipation of the Niger Delta, issued an explicit warning for Chinese companies to stay away and detonated bombs in the delta (Obi 2007). The devastating environmental impacts of oil production, spillages and gas flaring, in this region have been extensively detailed. One and half million tons of oil has been spilt there in the last 50 years (World Wildlife Fund cited in Ghazvinian 2007). Increased poverty and environmental degradation in the delta are implicated in conflict there, which claims roughly 1000 lives a year. Kidnapping and ransoming of expatriate oil workers in the delta is so rife that many have personal bodyguards, with one bar frequented by expatriates having barmats that read 'Eat a lot. Fat people are harder to kidnap' (Ghazvinian 2007, 80). In June 2007, 74 people were killed on an attack on a Chinese oil field in Ethiopia (Powell 2007).

Resource rents available from oil tend to discourage the development of a social or tax contract with citizens, and state accountability, as revenues 
are available to state elites from extractive enclave economies instead (Leonard and Strauss 2003). New possibilities for corruption are opened up in resource-rich states and Dutch disease may increase poverty and narrow the economic base (Gary and Reisch 2005). The re-inforcement of rentier 'petro-states' makes economic and social development harder and exacerbates class inequalities. You can now buy a US\$7000 candelabra in Angola's new US $\$ 35$ million shopping mall, while $70 \%$ of the country live below the poverty line (Perry 2007). In Nigeria, where hundreds of billions of dollars worth of oil have been pumped since the 1950s, $85 \%$ of revenues accrue to only 1\% of the population (International Crisis Group 2006 cited in Watts 2006).

Oil booms also seem to exacerbate spatial inequality within countries. While the genocide proceeds in Darfur, Sudan's economy is booming and a new 1500 acre office, duplex and golf course complex is being built in the capital, Khartoum (The Economist 2006c). Chinese support for Sudan's government in order to retain access to oil has been well documented (see Askouri 2007).

\section{Impacts of the Resource Boom on African Manufacturing}

Traditionally, manufacturing has been central to economic transformation as a seedbed of productivity increases, exports and innovation. The increased emphasis on oil and other mineral extraction, and the competitive displacement of much manufacturing as a result of reduced import barriers and appreciating currencies is resulting in a technological downgrading of African economies (Economist Intelligence Unit 2002). However, economic growth also opens up potential for manufacturing development.

As domestic demand has risen, and some new export opportunities are opened up, Kenya is growing manufacturing employment; creating 5500 new jobs in the sector in 2005, while certain branches such as leather and footwear decline, largely as a result of Chinese imports (Central Bureau of Statistics, Government of Kenya 2007).

Countries producing goods highly demanded by China (e.g. some minerals) may see export growth; those exporting products in competition with its output (such as clothing) will see exports fall, while countries importing those goods will gain from lower prices. (Stephens and Keenan 2006, 33)

China is now the 'workshop of the world'. It combines low-labour costs, with advanced infrastructure and skills and a 'market Stalinist' state (Henderson 1993), intent on maintaining Communist Party rule through a combination of economic growth and force. For example, it leads the world in executions, sometime using 'execution buses' (Lifesitenews 2005).

Most of the world's mobile phones are produced in China. It accounts for $80-90 \%$ of the world's production of soft toys and microwaves and one town - Qiatou or 'Button and Zip Town' - produces 60\% of the world's 
buttons and most of our zips (The Guardian 2005). In a context where African economies have been liberalised in the last 20 years, under the auspices of World Bank and IMF programmes, Chinese competition has exerted severe pressure on African manufacturers. Indeed, some speak of a Chinese textile tsunami sweeping over the continent, which it is estimated has resulted in the loss of hundreds of thousands of jobs (Carmody and Owusu 2007). In South Africa, 86\% of clothing imports are from China (van de Looy 2006) and most of those who have lost their jobs are women (Kaplinsky 2006b).

Competitive displacement from Asian imports is in part because of the poor capabilities in the sector. For example, all of Africa in 2002, excluding South Africa, had only $0.1 \%$ of the world's International Standards Organisation 9000 certificates (Lall 2005). These certs show quality management - a virtual prerequisite for potential exporters. The average productivity of Zambian firms is only one quarter that of Chinese ones (Arnold and Mattoo 2007).

A research group at the Institute of Development Studies in Sussex and Open University in the UK has begun to systematise the impacts of what they call the 'Asian Drivers' (China and India) on low-income economies around the world. Jenkins and Edwards (2006) calculate an export similarity index for African countries, China and India. Based on the standard industrial tariff classification, the country facing the greatest competition in Africa in international markets with China, is Lesotho where $89.1 \%$ of it exports (almost exclusively clothing), fall into categories in which China also exports. Its vulnerability to this competition was demonstrated in early 2005 when the Multi-Fibre Arrangement, which had set quotas on textile and clothing imports around the world, was phased out and the Basotho textile industry was devastated. Subsequently, it revived somewhat with the imposition of 'safeguard' import restrictions by the USA and European Union to protect from the Chinese import surge (see Carmody and Owusu 2007 for a discussion). However, these safeguard measures are temporary. Nonetheless, according to Broadman (2007a, 12), there is new investment forthcoming:

The vast majority of Chinese and Indian FDI inflows to Africa over the past decade have been largely concentrated in the extractive industries. Because such investments are typically capital intensive, they have engendered limited domestic employment creation. However, in the last few years Chinese and Indian FDI in Africa has begun to diversify into many other sectors, including apparel, agroprocessing, power generation, road construction, tourism and telecommunications, among others.

Revived economic growth offers the potential of some limited linkage and multiplier effects in non-tradables such as heavy mining equipment, which is 'naturally protected' by high transportation costs, and in services such as construction or mobile phone repair (interview with managers of Indo-Zambian Bank, Lusaka, Zambia, 4 January 2007; see also Kaplinsky 
2008). Debt relief and improved tax revenues mean governments have more money to invest in infrastructure and education and health, stimulating both direct job creation and wider benefits for economies. Also, as tax revenues have improved, government procurement has stimulated some new investment in manufacturing FDI. The Indian company Tata has recently opened a bus and truck assembly plant in Zambia; the output of which will be mostly bought by the government (India News 2006).

The growth of Asian economies has also opened up potential for increased manufactured exports; mostly lower value-added 'basic manufactures', such as aluminium, iron and steel. Exports of manufactures from Africa to China quadrupled from 1990 to 2004 to over US\$800 million (Broadman 2007a). China recently announced that it would increase the number of export items allowed into China from Africa's least developed countries, that recognise Beijing from 190 to 440 (Marks 2007). However, manufactured exports are still relatively small compared even to the amount of services (largely tourism) that Africa 'exports' - US $\$ 22$ billion in 2004. For example, the numbers of Chinese tourists going to Africa doubled from 2004 to 2005.

According to Broadman (2007a) Chinese and Indian FDI in manufacturing is propelling African producers into 'cutting edge transnational networks'. Thus, he argues that Africa is being integrated into global value or commodity chains originating in China and India and that this 'network trade' will facilitate the continent breaking out of its traditional static comparative advantage in raw material and natural resource intensive exports. Another way to put this is that Africa is experiencing 'deep' rather than 'shallow trade integration', which is where only the volume, price and direction, rather than the structure of trade changes (Evans et al. 2004, 2005 cited in Schmitz 2006). This is in sharp contrast to the arguments of Gibbon and Ponte (2005) who argue that Africa is 'trading down' in global value chains. Overall, while some local market serving investment in manufacturing is taking place in food processing and vehicle assembly, ${ }^{8}$ for example, by Asian companies in Africa, on the back of stronger economic growth, the competitive displacement pressures on African manufacturing are strong. Consequently, it is Asian and Western economies and actors that are capturing many of the benefits of African economic growth.

Chinese 'economic cooperation zones' hosting small- and medium-sized enterprises, such as the one in Sierra Leone, have a class impact, in that the indigenous business class remains underdeveloped (Himbara 1994). In Kenya, $75 \%$ of manufacturing is owned by the 175,000 strong 'Indian' population (Soludu and Ogbu 2004). Chinese companies can outcompete local rivals as they pay a 3\% interest rate on their loans in the textile and clothing industry, versus roughly 15\% for businesses in the Common Market of Eastern and Southern Africa region (Manchester Trade Team 2005 cited in Kaplinsky et al. 2006).

In Osikango, Namibia, Chinese traders sell a carton of 300 shoes for US $\$ 100$ (Kaplinsky et al. 2006), which no local producer can hope to 
compete with. 'Even in Angola's war-torn region of Huambo, five Chinese retailers have, since their arrival in 2000, managed to carve out a position that has effectively closed down established suppliers and retailers' (Alden 2005, 157). Thus, the gains from both trade and production are largely kept within ethnic business networks, rather than diffusing through local populations.

Infrastructure is a key constraint on manufacturing development in Africa. Forty per cent of Africans live in countries that are landlocked (Broadman 2007a). One Chinese firm in South Africa finds that sending products to Angola is as expensive as shipping them to China. While there are currently major infrastructure projects being put in place across the continent, Chinese companies often import up to $70 \%$ of the labour from China to work on these, reducing the impact on unemployment in African countries (Rocha 2006). However, the fact that China's US $\$ 1.3$ trillion of foreign exchange reserves may now be used for overseas investment projects opens up great potential for infrastructural transformation in Africa, such as the recently announced US $\$ 5$ billion road and rail for debt package for the DRC (Alden 2007; The Economist 2007). ${ }^{9}$

\section{Future Prospects: Post-Neoliberalism and Industrialisation in Africa?}

While many of Africa's economies have experienced some recent recovery in macro-economic aggregates, the impacts of this should not be exaggerated. Sub-Saharan Africa's total economic output is equivalent to that of Belgium or Texas. The average size of an African country's economy is around the size of a town of 60,000 people in the rich world (World Bank 2000). Africa's average economic output per person is lower now than it was 30 years ago, and consequently there is substantial potential for catch-up growth, even to get back to that level (Nyamugarisa 2000 cited in African Development Bank 2006). Even with relatively rapid economic growth, the social fabric in many African countries is badly tattered as a result of decades of economic stagnation. In the early 1990s, children under five in SSA were 19 times more likely to die than their counterparts in the rich countries. By 2003, they were 26 times more likely to be dead by age five (United Nations Development Program 2003 cited in Kirby 2006).

Economic recovery in Africa has been driven by the confluence of regional and global factors, particularly the interaction and 'externalisation' of the South African, Chinese and US economies, as they are increasingly dependent on the resources and markets of other countries for their growth. However, as other countries' economies in the region are shaped by imperatives originating elsewhere, economic recovery has remained shallow; largely confined to reinvigorating the colonial trade structure.

A key question is whether the current economic recovery will attract back African 'flight' and human capital, essential to sustained economic recovery 
(Taylor 2005b). As Paul Collier (2007, 175), formerly of the World Bank concludes in relation to the impacts of globalisation on the world's poorest countries: "trade is more likely to lock them into natural resource dependence than to open new opportunities, and the international mobility of capital and skilled workers is more likely to bleed them of their scanty capital and talent than to provide an engine of growth.'

In 1999, there were more than 30,000 Africans with PhDs living outside the continent (Cogburn and Adeya 1999 cited in Ya'u 2006) and 130,000 university graduates leave the continent each year (Wilmot 2002 cited in Moyo 2006). While they are educated using taxpayers money, there are more Malawian doctors in Birmingham in the UK than there are left in Malawi (Royal African Society 2005). On the other hand, the 100,000 US dollar millionaires on the continent keep much of their assets overseas (Taylor 2005b).

The indications on capital reinvestment in Africa are not promising. Investment as a percentage of GDP remains stuck at around 20\% for the last 4 years and productivity remains low (IMF 2007; Ndulu et al. 2007), unlike in China where gross fixed capital formation accounts for over $40 \%$ of nominal GDP (Qin et al. 2006). Thus, Africa's current growth cycle is factor (resource) rather, than investment or innovation driven and consequently its sustainability is open to question, with long-term negative implications for poverty, in the absence of substantial economic diversification. While the impacts of commodity boom have been nationally and regionally differentiated it has been very environmentally, and relatively capital-intensive, so the indications are that it will not lead to dramatic and sustainable reductions in unemployment and poverty.

Greater Chinese influence may, however, allow for more pragmatism in economic policy-making. As Joseph Stiglitz (1998, 22) noted:

China extended the scope of competition without privatising state-owned enterprises . . . Chinese policymakers not only eschewed a strategy of outright privatisation, they also failed to incorporate other elements of the (orthodox) Washington Consensus. ${ }^{10}$

China is now an alternative source of loans to the World Bank and IMF, recently providing US $\$ 2$ billion to Angola. Thus, the pace at which economic liberalisation is proceeding on the continent has slowed (Frazer Institute 2006 cited in Economist Intelligence Unit 2006). Is there then more 'policy space' (Gallagher 2005) for domestic innovation or just a different master? A report for the European Parliament asks whether China 'will become the world's first industrial superpower without having to resort to colonial practices?' given domestic 'overcapacity, saturation of the domestic market [and] the need for raw materials' (Holslag et al. 2007, 52), although Chinese involvement in Africa involves many different motivations and dimensions (Alden 2007).

The challenge for Africa is to move up the value chain, into manufacturing production and higher value-added services, to create substantial 
numbers of higher paying jobs, while also taking advantages of opportunities in other sectors (Söderbom and Teal 2003); 'decoupling' economic growth from massive environmental degradation, and providing resources to deal with other challenges such as HIV/AIDS, which has been described as 'running Adam Smith in reverse' in the worst affected countries (McPherson 2003 cited in de Waal 2006; see also Pollin et al. 2007). In the short term, two potential areas where there is substantial scope for the development of indigenous manufacturing are in agro-processing, which may be very labour-intensive, and mineral beneficiation (Cramer 1999). For example, even though Mali is the world's fifth largest cotton producer, it processes only $2 \%$ of its crop locally (Siddiqi 2007a). However, in the medium term, the focus should be on a widening of industrialisation beyond these subsectors.

The increasing dependence of African economies on natural resources fits into the historical continuum of extractive globalisation that has characterised the continent's engagement with the outside world (Bond 2006). However, this may change in the future. Gibbon and Ponte $(2005,203)$ argue that as labour costs rise 'as China itself becomes more economically mature, the prospects for Africa to build on [its manufacturing] experiences are reasonably promising'. This will require effective innovation management, the institution of strategic trade and industrial policies and the reconstruction of African states so that have the autonomy (from donors in particular) and capacity to implement them (Kaplinksy 2005; Soludo et al. 2004). How to capitalise on the window of opportunity offered by recent economic growth is the key challenge for donors, African populations and policymakers.

Sustainable poverty reducing integration into the global economy will require appropriate institutions, social capabilities, technologies and infrastructures. As things stand few African countries would appear to have the class structures and institutions to effectively capture and 'sow' oil and mineral rents for structural transformation. The underdevelopment of domestic capital and labour has serious consequences for governance, as it is these social forces that have historically held the state accountable in industrial societies (see Carmody 2007). However, there is some local business development taking place (Fick 2006) and trade unions are mobilising in some countries, such as Zambia, around exploitative labour conditions and practices. The last great commodity boom after the World War II was associated with the development of organised labour and local business, which were instrumental in throwing off the shackles of an unaccountable colonialism (Sender and Smith 1986). They may yet contribute to a new 'second liberation'.

\section{Acknowledgements}

The author would like to thank Jim Glassman, Francis Owusu, Howard Stein, Cheryl McEwan and two anonymous referees for their helpful and insightful comments. Any mistakes or ommissions are the author's. 


\section{Short Biography}

Pádraig Carmody is Lecturer in Geography at Trinity College Dublin and editor of Irish Geography. His research centres on the political economy of globalisation and restructuring in Africa. He has published in the Review of African Political Economy, Economic Geography, Political Geography, and the Journal of Southern African Studies, among others. He has consulted for the South African government, and previously taught at St. Patrick's College, Dublin City University and the University of Vermont. He is a graduate of the University of Dublin and holds a PhD from the University of Minnesota.

\section{Notes}

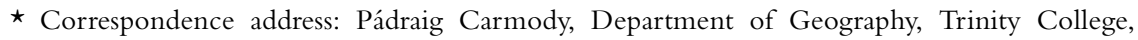
Dublin 2, Ireland. E-mail: carmodyp@tcd.ie.

${ }^{1}$ Although per capita growth is considerably less impressive given that Africa has the highest rate of population growth in the world.

${ }^{2}$ Perhaps analagous to the unlocking of the cryptex in The Da Vinci Code. This may occur through a concurrence of changes in patterns of global capital accumulation and through purposive public action.

${ }^{3}$ Plunder refers to the theft of resources through force, which has been much in evidence in Africa. Others refer to this as 'accumulation by dispossession' (Harvey 2003).

${ }^{4}$ In part, this may also be because of suspected collusion between the two main multinational tobacco buying firms in the country to keep prices down. Anxious to maintain its diplomatic support at the UN, Taiwan has recently announced that it will buy tobacco directly from Malawi, cutting out the 'middlemen' (Afriqueligne 2007).

5 'Cost-down' is where suppliers are expected to reduce their prices, year-on-year. 'Cross-costing' is where buyers' source quotes from different suppliers putting them in competition with each other. ${ }^{6}$ These supplanted World Bank/IMF structural adjustment programmes in 1999.

${ }^{7}$ Soon after this TESCO introduced stickers on its products showing the number of air miles they had travelled so that consumers could not buy them if they wished to be "environmentally friendly'. However, the UK Secretary for International Development has noted Kenyan flowers only use $20 \%$ of the energy that Dutch flowers do, including transportation, because they are not grown in heated greenhouses.

${ }^{8}$ Given high-labour productivity, South Africa has established itself as a major exporter of cars, including the recent commissioning of a General Motor 'Hummer' assembly plant to serve the African, European and Asian market; the first of its kind outside the USA.

${ }^{9}$ For comparison, US forex reserves stand at about US $\$ 68$ billion, or $5.2 \%$ of Chinese reserves.

${ }^{10}$ Free market reforms promoted by the IMF and World Bank.

\section{References}

African Business. (2007). Africa's top 100 banks. African Business. [online]. Retrieved on 2 October 2007 from http://www.africasia.com/africanbusiness/ab.php?ID=1461\#

African Development Bank. (2006). African development report 2006: aid, debt relief and development in Africa. Oxford, UK: Oxford University Press.

Africa Monitor. (2007). Africa's leap over landlines. Africa Monitor: Southern Africa 12 (9), pp. 1 and 6.

Afriqueligne (2007). Taiwan to directly buy Malawi tobacco this year. [online]. Retrieved on 22 July 2007 from http://www.afriquenligne.fr/news/daily_news/taiwan_to_directly_buy_malawi_ tobacco _this_year_200707172986/ 
Alden, C. (2005). China in Africa. Survival 47 (3), pp. 147-164.

- (2007). China in Africa. London and New York: Zed Book/Cape Town, South Africa: David Philip.

Amoako, K. Foreword in Economic Commission for Africa. (2003) Economic report on Africa 2003: accelerating the pace of development. Addis Ababa, Ethiopia: ECA.

Arnold, J., and Mattoo, A. (2007). Services in the Zambian economy. In: Mattoo, A. and Payton, L. (eds) Services trade and development: the experience of Zambia. Basingstoke, UK: Palgrave MacMillan for the World Bank, pp. 61-100.

Askouri, A. (2007). China's investment in Sudan: Displacing villages and destroying communities. In: Manji F. and Marks S. (eds) African perspectives on China in Africa. Cape Town, South Africa: Fahamu, pp. 71-86.

BBC. (2002). Corruption 'costs Africa billions'. [online]. Retrieved on 5 December 2006 from http://news.bbc.co.uk/1/hi/world/africa/2265387.stm

Benner, C. (2006). South Africa on-call: information technology and labour restructuring in South African call centres. Regional Studies 40 (2), pp. 1025-1040.

Billon, P. (2007). Geographies of war: perspectives on 'resource wars'. Geography Compass 1/2, pp. 163-182. [online]. Retrieved on 5 July 2007 from http://www.blackwell-compass.com/ subject/geography/article_view?article_id=geco_articles_bpl010

Bond, P. (2005). Neoliberalism in sub-Saharan Africa: From structural adjustment to NEPAD. In: Saad-Filho, A. and Johnston, D. (eds) Neoliberalism: a critical reader. London: Pluto Press, pp. $230-236$.

. (2006). Looting Africa: the economics of exploitation. London: Zed Book.

Broadman, H. (2007a). Africa's silk road: China and India's new economic frontier. Washington, DC: World Bank.

—. (2007b). Connecting Africa and Asia. Finance and Development 44 (2). [online]. Retrieved on 27 September 2007 from http://www.imf.org

Bush, R. (2007). Poverty and neoliberalism: persistence and reproduction in the global south. London: Pluto Press.

C/NET (2001). Server farms on the hot seat amid power woes. [online]. Retrieved on 30 September 2007 from http://www.news.com/2100-1017-257567.html?legacy $=$ cnet

CNN. (2006). Congo's Tin Men. May 4th.

Carmody, P. (2001). Tearing the social fabric: neoliberalism, deindustrialization and the crisis of governance in Zimbabwe. Portsmouth, NH: Heinemann.

- (2005). Transforming globalization and security: Africa and America post-9/11. Africa Today 52 (1), pp. 97-120.

- (2007). Neoliberalism, civil society and security in Africa. Basingstoke, UK: Palgrave MacMillan.

Carmody, P., and Owusu, F. (2007). Competing hegemons? Chinese versus American geo-economic strategies in Africa. Political Geography 26, pp. 504-524.

Cassim, R., and Mayer, M. (1997). Regional industrial development. In: Kritzinger-van L. N. (ed.) Toward strengthening multisector linkages in SADC. Midrand, South Africa: Development Bank of Southern Africa, pp. 43-68.

Castells, M. (1998). End of millennium. Oxford and Malden, MA: Blackwell.

Central Bureau of Statistics, Government of Kenya (2007). Kenya Economic Survey 2005. [online]. Retrieved on 25 September 2007 from http://www.cbs.go.ke

Chan-Fishel, M. (2007). Environmental impact: more of the same? In: Manji F., and Marks S. (eds) African perspectives on China in Africa. Cape Town, South Africa: Fahamu, pp. 139-152.

Cheru, F. (1989). The silent revolution in Africa: debt, development, democracy. London: Zed Books.

Clapham, C. (2006). Fitting China in. Brenthurst Discussion Papers 8/2006. Johannesburg, South Africa: Brenthurst Foundation.

Cogburn, D., and Adeya, C. N. (1999). Globalization and the information economy: challenges and opportunities for Africa. Paper presented at the African Development Forum, Addis Ababa. [online]. Retrieved on 27 July 2007 from http://www.unu.edu/africa/papers/cogburn-adeya.pdf

Collier, P. (2007). The bottom billion: why the poorest countries are failing and what can be done about it. Oxford, UK: Oxford University Press.

Collier, P., and Bannon, I. (2003). Natural resources and Civil War. Washington, DC: World Bank. Copson, R. (2007). The United States in Africa: Bush policy and beyond. London: Zed Books. 
Council on Foreign Relations. (2007). Business principles for a strong Africa. [online]. Retrieved on 30 September 2007 from http://craigeisele.wordpress.com/2007/09/23/proposed-businessprinciples-for-a-strong-africa/

Cramer, C. (1999). Can Africa industrialize by processing primary commodities? The case of Mozambican Cashew nuts. World Development 27 (7), pp. 1247-1266.

Cramer, C. (2006). Civil war is not a stupid thing: accounting for violence in developing countries. London: Hurst.

CSO (Central Statistics Office). (2007). Monthly digest of statistics. [online]. Retrieved on 7 November 2007 from http://www.zamstats.gov.zm

De Janvry, A. (1981). The Agrarian question and reformism in Latin America. Baltimore, MD: Johns Hopkins University Press.

De Waal, A. (2006). AIDS and power: why there is no political crisis yet. London: Zed.

Dixon, R. (2006). Africans lash out at Chinese employers. Los Angeles Times. [online]. Retrieved on 20 July 2006 from http://www.hermes-press.com/africans_protest.htm

Dumas, C., and Choylevam, D. (2006). The bill from the China shop: how Asia's savings glut threatens the world economy. London: Profile Books.

Duncombe, R. (2006). Using the livelihoods framework to analyze ICT applications for poverty reduction through microenterprise. Information Technologies and International Development 3 (3), pp. 81-100.

Economist Intelligence Unit. (2002). Business Africa 1st September. London: Economist Intelligence Unit.

-. (2006). Business Africa 1st October. London: Economist Intelligence Unit.

English, P., et al. (2006). Exporting out of Africa: the Kenya horticulture success story. In: Fox, L. and Liebenthal, R. (eds) Attacking Africa's poverty: Experience from the ground. Washington, DC: World Bank.

Evans, D., et al. (2004). A framework for evaluating regional trade agreements: deep integration and new regionalism, report to DFID, mimeo, University of Sussex, December.

Evans, D., et al. (2005). A framework for evaluating regional trade agreements involving developing countries, report to DFID, mimeo, University of Sussex, March.

Fick, D. (2006). Africa: Continent of economic opportunities. Johannesburg, South Africa: STE Publishers.

Fine, B., and Rustomjee, Z. (1996). The political economy of South Africa: From minerals-energy complex to industrialization. London: Hurst.

Frazer, J. (2006). Current themes in U.S. Africa policy. [online]. Retrieved on 20 July 2007 from http://www.state.gov/p/af/rls/rm/2006/69321.htm

Frynas, J. G., and Paulo, M. (2007). A new scramble for African oil? Historical, political and business perspectives. African Affairs 106 (423), pp. 229-252.

Gallagher, K. (2005). Putting development first: the importance of policy space in the WTO and international financial institutions. London: Zed.

Gary, I., and Reisch, N. (2005). Chad's oil: Mirage or miracle? Following the Money in Africa's newest petro-state. Washington, DC: Catholic Relief Services and Bank Information Centre.

Ghazvinian, J. (2007). Untapped: The scramble for Africa's oil. Orlando, FL: Harcourt.

Gibbon, P., and Ponte, S. (2005). Trading down: Africa, value chains and the global economy. Philadelphia, PA: Temple Press.

Gillwald, A. (2005). Introduction. In: Gillwald, A. (ed.) Towards an African e-index: Household and individual ICT access and usage across 10 Africa countries. Johannesburg, South Africa: RIA.

Goldstein, A. (2006). An outlook for Africa, presentation of report findings at Chatham House, London, 15 June. [online]. Retrieved on 10 May 2006 from http://www.chathamhouse.org.uk

Hanlon, J. (2004). Do donors promote corruption? The case of Mozambique. Third World Quarterly 25 (4), pp. 747-763.

Harvey, D. (2003). The new imperialism. Oxford, UK: Oxford University Press.

Hazelhurst, E. (2007). China is now SA's fifth biggest export market, data show. Business Report. [online]. Retrieved on 3 October 2007 from http://www.busrep.co.za

Henderson, J. (1993). The role of the state in the economic transformation of East Asia. In: Dixon, C. and Drakakis-Smith, D. (eds) Economic and social development in the Asia Pacific. London: Routledge, pp. 85-114.

Hentz, J. (2005). South Africa and the logic of regional cooperation. Bloomington, IN: Indiana University Press. 
Hertz, N. (2004). I.O.U.: the debt threat and why we must defuse it. London: Fourth Estate.

Himbara, D. (1994). Kenyan capitalists, the state and development. Boulder, CO: Lynne Rienner.

Hirsch, A. (2005). Season of hope: economic Reform under Mandela and Mbeki. Durban, South Africa: University of Kwa-Zulu Natal Press.

Holslag, J., et al. (2007). Chinese resources and energy policy in Sub-Saharan africa: report for the development committee of the European Parliament. Brussels, Belgium: European Union.

Hoogvelt, A. (1997). Globalization and the post-colonial world. Baltimore, MD: Johns Hopkins University Press.

Human Security Centre. (2005). Human security report 2005: War and peace in the twenty first century. Oxford, UK: Oxford University Press.

Humphrey, J. (2007). The supermarket revolution in developing countries: tidal wave or tough competitive struggle. Journal of Economic Geography 2, pp. 433-450.

IMF. (2007). World economic and financial surveys: world economic outlook database, October 2007 edition. [online]. Retrieved on 26 November 2007 http://www.imf.org/external/pubs/ft/ weo/2007/02/weodata/index.aspx

India News. (2006). President Mwanawasa commissions Tata Zambia assembly plant. Lusaka, India: Indian High Commmission.

Integrated Regional Information Network. (2006). South Africa: jobs up, but numbers not high enough-economists. [online]. Retrieved on 9 December 2006 http://medilinkz.org/news/ news2.asp?NewsID=18044

International Crisis Group. (2006). Nigeria: want in the midst of plenty, Africa Report 113.

James, J. (2002) Technology, globalization and poverty. Cheltenham, UK: Edward Elgar.

Jenkins, R., and Edwards, C. (2006). The Asian drivers and sub-Saharan Africa. IDS Bulletin 37 (1), pp. 23-32.

Kaminski, M. (2007). The Mozambique miracle. The Wall Street Journal 10 April, p. 17.

Kaplinksy, R. (2005). Globalization, poverty and inequality: between a rock and a hard place. Oxford, UK: Polity.

- (2006a). China and the global terms of trade. IDS Bulletin 37 (1), pp. 43-53.

- (2006b). Winners and losers: China's trade threats and opportunities for Africa. In: Wild L. and Mepham D. (eds) The new Sinosphere: China in Africa. London: Institute for Public Policy Research, pp. 12-22.

- (2008). What does the rise of China do for industrialisation in SSA? Review of African political economy, Special Issue on 'Good Friends, Good Partners, Good Brothers: The 'New' Face of Sino-African Co-operation', March.

Kaplinsky, R., McCormick, D., and Morris, M. (2006). The impact of China on sub-Saharan Africa. [online]. Retrieved on 12 June 2006 from http://www.ids.ac.uk

Kaunda, F. (2002). Selling the family silver: the Zambian copper mines story. Kwa-Zulu Natal, Zambia: Interpak.

Keet, D. (2006). The character and role of trade within NEPAD. In: Adésínà J.O., Graham, Y. and Olokoshi, A. (eds) Africa and development: challenges in the new millennium: the NEPAD debate. Dakar, Senegal: CODESRIA, pp. 152-177.

Kiely, R. (2007). Poverty reduction through liberalization. Review of International Studies 33 (3), pp. 415-434.

Kirby, P. (2006). Vulnerability and violence: the impact of globalization. London: Pluto.

Klare, M. (2005). Blood and oil: how America's thirst for petrol is killing us. London: Penguin.

Knox, P., and Agnew, J. (1998). The geography of the world economy, 3rd ed. London: Arnold.

Lall, S. (2005). Industrial competitiveness in Africa: lessons from East Asia. Warwickshire, UK: ITDG Publishing.

Lemos, A., and Ribeiro, D. (2007) Taking ownership or just changing owners. In: Manji, F. and Marks, S. (eds) African perspectives on China in Africa. Cape Town, South Africa: Fahamu, pp. 63-70.

Leonard, D. K., and Strauss, S. (2003). Africa's stalled development: international causes and cures. Boulder, CO: Lynne Rienner.

Lifesitenews (2005). China Moves from bullets to mobile execution vans to improve international image. [online]. Retrieved on 27 September 2005 from http://www.lifesite.net

Lockwood (2005). The state they're in: an international agenda for poverty in Africa. Warwickshire, UK: ITDG Publishing. 
Londsdale, J. (1981). States and social processes in Africa: a historiographical survey. African Studies Review XXIV (2/3), pp. 139-225.

Lovering, J. (1989). The restructuring debate. In: Peet, R. and Thrift, N. (eds) New models in geography: the political economy perspective. London: Unwin Hyman, pp. 198-223.

Manchester Trade Team. (2005). Impact of the End of MFA Quotas and COMESA's Textile and Apparel Exports under AGOA: Can the Sub-Saharan Africa Textile and Apparel Industry Survive and Grow in the Post-MFA World? Report prepared for USAID East and Central Africa Global Competitiveness Trade Hub.

Marks, S. (2007). Introduction. In: Manji, F., and Marks, S. (eds) African perspectives on China in Africa. Cape Town, Nairobi and Oxford: Fahamu.

Mawdsley, E. (2007). China and Africa: emerging challenges to the geographies of power, geography compass. [online]. Retrieved on 26 July 2007 from http://www.blackwell-compass.com/subject /geography/article_view?article_id=geco_articles_bpl019

McCormack, R. (2006). China replaces the USA as world's largest exporter. Manufacturing and Technology News 13 (16), pp. 1-3.

McPherson, M. (2003) Non-linear macro effects of HIV/AIDS: an overview. USAID EGAT/ED/ HEW and Centre for Business and Government. Harvard, Mimeo: JFK School of Government.

Mining Review. (2004). Reclaiming one of SA's largest slag heaps. [online]. Retrieved on 25 July 2007 from http://www.miningreview.com/archive/mra_6_2004/16_1_1.php

Mittelman, J. (2000). The globalization syndrome: transformation and resistance. New Have, NJ: Princeton University Press.

Mkandawire, T. (2005). The Global Economic Context. In: Toulmin, C., Wisner, B. and Chitiga, R. (eds) Towards a new map of Africa. London: Earthscan and IIED.

- (2007). Good governance: the itinerary of an idea. Development in Practice 17 (4-5), pp. 679-681.

Moyo, S. (2006). Africa's agrarian transformation: the efficacy of the NEPAD agriculture strategy. In: Adésínà J. O., Graham, Y. and Olokoshi, A. (eds) Africa and development: challenges in the New Millennium: the NEPAD debate. Dakar, Senegal: CODESRIA, pp. 107-139.

Muir, H. (2004). Manhole cover vanish in the night. The Guardian, 24 October. [online]. Retrieved on 25 July 2007 from http://www.guardian.co.uk/uk_news/story/0,3604,1335156,00.html

Mulenga, C. (2006). Zambia, China firm seal $\$ 200 \mathrm{~m}$ deal. Zambia Daily Mail 10 November, p. 1.

Muloney, T. (2006). 'I don't trust the phone; it always lies': trust and information and communication technologies in Tanzanian micro- and small enterprises. Information Technologies and International Development 3 (4), pp. 67-83. .

Mytelka, L. (2003). The dynamics of catching up: The relevance of an innovation system approach in Africa. In: Muchie M., Gammeltoft, P. and Lundvall, B. (eds) Putting Africa first: The making of African innovation systems. Aalborg, Denmark: Aalborg University Press, pp. 29-42.

Naidu, S. (2006). China-African Relations in the 21st Century: a 'win-win' relationship in China in Africa. Uppsala, Sweden: Nordiska Afrikainstitutet.

Ndulu, B., et al. (2007). Challenges of African Growth: opportunities, constraints and strategic directions. Washington, DC: World Bank.

Nest, M., Grignon, F., and Kisangani, E. F. (2006). The Democratic Republic of Congo: economic dimensions of war and peace. Boulder, CO: Lynne Rienner.

New Partnership for Africa Develoment. (2001). Retrieved on 27 July 2007 from http:// www.nepad.org/2005/files/home.php

Nyamugarisa, W. (2000). Aid conditionality, policy ownership and poverty reduction: a southern perspective on critical issues, constraints and opportunities. Costa Rica: The Reality of Aid Project.

O'Connor, M. (ed.) (1994). Is capitalism sustainable? Political economy and the politics of ecology. London: Guilford.

Obi, C. (2007). Enter the dragon? Chinese oil companies and the politics of local resistance in the Niger Delta, Nigeria. Paper presented at the Leeds University Centre for African Studies/Third World Network and Review of African Political Economy Conference on the State Mining and Development in Africa, 13-14 September 2007.

Okpaku, J. O. (2006). Leapfrogging into the information economy: harnessing information and communications technologies in Botswana, Mauritania and Tanzania. In: Fox, L. and Liebenthal, R. (eds) Attacking Africa's poverty: experience from the ground. Washington, DC: World Bank. 
Oloja, M., et al. (2007). Okonjo-Iweala resigns. [online]. Retrieved on 27 November 2007 from http://www.guardiannewsngr.com/news/article01/040806

Omeje, K. (2005). Oil conflict in Nigeria: contending issues and perspectives on the local Niger Delta people. New Political Economy 10 (3), pp. 322-334.

Organisation for Economic Cooperation and Development and African Development Bank. (2006). African economic outlook 2005/6: a two-speed continent? Paris, France: OECD.

Pan, E. (2006). China, Africa and oil. Council on foreign relations. [online]. Retrieved on 7 December 2006 from http://www.cfr.org

Pempel, T. J. (1999). The developmental regime in a Changing World. In: Woo-Cummings, M. (ed.) The developmental state. Ithaca, NY: Cornell University Press.

Perez, C. (2002). Technological revolutions and financial capital: the dynamics of bubbles and golden ages. Cheltenham, UK: Edward Elgar.

Perry, A. (2007). Africa's oil dreams. Time 11 June, pp. 24-31.

Pogge, T. (2002). World poverty and human rights: cosmopolitan responsibilities and reforms. Oxford, UK: Polity.

Pollin, R., et al. (2007). An employment targetted program for South Africa. Cheltenham, UK: Edward Elgar.

Powell, A. (2007). Officials: 74 dead in attack on Chinese oil fields in Ethiopia. The Independent 13 June. [online]. Retrieved on 15 July 2007 from http://news.independent.co.uk/world/ africa/article2483830.ece

Qin, D., et al. (2006). How much does investment drive economic growth in China? Journal of Policy Modelling 28 (7), pp. 751-774.

Ramo, J. (2004). The Beijing Consensus. London: Foreign Policy Centre.

RNCOS (2006). African mobile handset market analysis (2006-2009). Description retrieved on 25 July 2007 from http://www.researchandmarkets.com/reportinfo.asp?report_id=329315

Rocha, J. (2006). Managing natural resource wealth: African strategies for China. In: Wild, L. and Mepham, D. (eds) The new Sinosphere: China in Africa. London: Institute for Public Policy Research, pp. 29-36.

- (2007). A new frontier in the exploitation of Africa's natural resources: the emergence of China. In: Manji, F. and Marks, S. (eds) African perspectives on China in Africa. Cape Town, South Africa: Fahamu, pp. 15-34.

Rowell, A., Marriot, J., and Stockman, L. (2005). The next gulf: London, Washington and oil conflict in Nigeria. London: Constable.

Royal African Society. (2005). A message to world leaders: what about the damage we do to Africa? London: Royal African Society.

Sauper, H. (2006). Darwin's Nightmare. Potential Films.

Sautman, B., and Hairong, Y. (2006). Honour and shame? China's Africa ties in comparative context. In: Wild, L. and Mepham, D. (eds) The new Sinosphere: China in Africa. London: Institute for Public Policy Research, pp. 54-61.

Schmitz, H. (2006). Asian drivers: typologies and questions. IDS Bulletin 37 (1), pp. 54-61.

Sender, J., and Smith, S. (1986). The development of capitalism in Africa. London: Metheun.

Shaxson, N. (2007). Poisoned wells: the dirty politics of African oil. Basingstoke, UK: Palgrave MacMillan.

Shinan, L. (2005). Severely punish theft of manhole covers. China Daily 21 December. [online]. Retrieved on 25 July 2007 from http://www.chinadaily.com.cn/opinion/2005-12/21/ content_536968.htm

Siddiqi, M. (2007a). Industrialization cannot wait. African Business 333, pp. 20-24.

-. (2007b). Copper is the star as Africa enjoys price boom. African Business 333, pp. 20-24.

Söderbaum, F. (2004). The political economy of regionalism: the case of Southern Africa. Basingstoke, UK: Palgrave MacMillan.

Söderbom, M., and Teal, F. (2003). How can policy towards manufacturing in Africa reduce poverty? A review of the current evidence from cross-country firm studies. Oxford, UK: Centre for the Study of African Economies.

Soludo, C., and Ogbu, O. (2004). A synthesis of major themes in the political economy of trade and industrialization in Africa. In: Soludo C., Ogbu, O. and Chang, H. J. (eds) The politics of trade and industrial policy in Africa: forced consensus? Trenton, NJ: Africa World Press and International Development Research Centre, pp. 1-42. 
Soludo, C., et al. (2004). The politics of trade and industrial policy in Africa: forced consensus? Trenton, NJ: Africa World Press and International Development Research Centre.

Southey, C. (2006). Chinese investor takes $\$ 800 \mathrm{~m}$ stake in Anglo American. Irish Times 11 November, p. 21.

Stein, H. (2007). The African development challenge. Lecture presented to Cambridge Advanced Program on Rethinking Development Economics (CAPORDE program), 10 July.

Stephens, C., and Keenan, J. (2006). How to identify the trade impact of China on small countries. IDS Bulletin 37 (1), pp. 33-42.

Stiglitz, J. (1998). More instruments and broader goals: moving towards the post-Washington consensus, WIDER Annual Lecture. Helsinki, Finland: UNU World Institute for Development Economics Research.

—. (2005). Development policies in a world of globalization. In: Gallagher, K. (ed.) Putting development first: the importance of policy space in the WTO and international financial institutions. London: Zed Books, pp. 15-32.

Taylor, I. (2005a). NEPAD: towards Africa's development or another false start? Boulder, CO: Lynne Rienner.

- (2005b). 'Advice is judged by results not intentions': why Gordon Brown is wrong about Africa. International Affairs 81 (2), pp. 299-310.

- (2006). China's oil diplomacy in Africa. International Affairs 82 (5), pp. 937-959.

The Economist (2006a). Mobile telecoms: out of Africa. The Economist 9 December, pp. 65-66. . (2006b). Mining in Zambia: the copper phoenix. The Economist. [online]. Retrieved on

12 August 2006 from http://www.economist.com/business/displaystory.cfm?story_id=

E1_GJVGTVD

- (2006c). Glittering towers in a war zone. The Economist 9 December, pp. 21-23.

. (2007). Who benefits from the minerals? A review of mining contracts may well be a sham. The Economist 20 September. [online]. Retrieved on 1 September 2007 from http:// www.economist.com/world/africa/displaystory.cfm?story_id=9833457

—. (2005). China and commodities: from accelerator to brake. The Economist. [online]. Retrieved on 12 August 2006 from http://www.economist.com/finance/displaystory.cfm?story_id=4488944

The Guardian (2006). The tigers teeth, 25 May. [online]. Retrieved on 25 July 2007 from http:// www.guardian.co.uk/g2/story/0,1491380,00.html

Toyne, P., O'Brian, C., and Nelson, R. (2002). The timber footprint of the G8 and China: making the case for green procurement by government. WWF International. [online]. Retrieved on 26 July 2007 from assets.panda.org/downloads/G8_meeting_June2002.pdf

United Nations. (2007). Africa and the millennium development goals. [online]. Retrieved on 19 July 2007 from http://www.un.org/millenniumgoals/

United Nations Conference on Trade and Development. (2005). Transnational corporations and internationalization of $R$ and D. [online]. Retrieved on 27 July 2007 from http:// www.unctad.org/en/docs/wir2005ch9_en.pdf

United Nations Development Program. (2003). Human development report 2003. Oxford, UK: Oxford University Press.

United States International Trade Commission. (2007). Industry and trade summaries. [online]. Retrieved on 27 November 2007 from http://www.usitc.gov/publications/index.htm

Unstrung (2007). NSN targets Africa. [online]. Retrieved on 22 July 2007 from http:// www.unstrung.com

Van de Looy, J. (2006). Africa and China: a strategic partnership? ASC Working Paper 67.

Van de Waal, N. (2001). African economies and the politics of permanent crisis. Cambridge, UK: Cambridge University Press.

Vidal, J. (2006). How your supermarket flowers empty Kenya's rivers. The Guardian 21 October. [online]. Retrieved on 26 July 2007 from http://www.guardian.co.uk/kenya/story/ $0,1928004,00 \cdot h$ tml

Voltairenet (2007). Sub-Saharan economies are growing faster but are they really growing stronger? [online]. Retrieved on 15 September 2007 from http://www.voltairnet.org/article141702.html

Von Braun, J., and Torero, M. (2006). Introduction and overview: In: Torero, M. and Von Braun, J. (eds) Information and communication technologies for development and poverty reduction. Baltimore, MD: Johns Hopkins University Press, pp. 1-20.

Wamwere, S. (2003). Negative ethnicity: from bias to genocide. New York: Seven Stories Press. 
Watts, M. (2006). Empire of oil: capitalist dispossession and the scramble for Africa. Monthly Review 58 (1), pp. 1-15.

Wehrfritz, G. (2007). The butterfly effect: why China can't save the world from recession. Newsweek 1 October, pp. 32-37.

Wilmot, P. (2002). A future that works. News Africa 1, p. 28.

World Bank. (2000). Can Africa claim the 21st century. Washington, DC: World Bank. - (2001). Global economic prospects. Washington, DC: World Bank.

. (2004). Cost, financing and school effectiveness of education in Malawi: a future of limited choices and endless opportunities. Africa Region Human Development Working Paper Series. Washington, DC: World Bank.

. (2006a). Recent economic performance in sub-Saharan Africa 12 April, pp. 1-7.

. (2006b). Africa development indicators 2006: from promises to results. Washington, DC: World Bank.

- (2006c). Where is the wealth of nations: measuring capital for the twenty-first century. Washington, DC: World Bank.

. (2007). Governance matters 2007: worldwide governance indicators 1996-2006. Washington, DC: World Bank.

Ya'u, Y. Z. (2006). Confronting the digital divide: an interrogation of African initiatives to bridge the gap. In: Adésínà, J. O., Graham, Y. and Olokoshi, A. (eds) Africa and development: challenges in the new millennium: the NEPAD debate. Dakar, Senegal: CODESRIA, pp. 178196.

Zafar, A. (2007). The growing relationship between China and sub-Saharan Africa: macroeconomic, trade, investment and aid links. World Bank Research Observer 22 (1), pp. 103-130. 